\title{
Silase Ampas Sagu Menggunakan Tiga Bahan Aditif sebagai Pakan Basal Kambing Boerka Fase Pertumbuhan
}

\author{
(Sago Waste Silage with Three of additives as Basal Diet for Growing Boerka Goat)
}

\author{
Simanihuruk K, Sirait J \\ Loka Penelitian Kambing Potong, PO Box 1 Sungai Putih,Galang, Sumatera Utara 20585 \\ kistonsimanihuruk@yahoo.com
}

\begin{abstract}
Sago waste is a by-product from sago palm that processed to be sago-meal, which is potential to be used as goat's feed. The aim of this research was to study the effect of sago waste silage as basal diet for growing Boerka goats. Twenty four male Boerka goats on growth phase (average initial body weight $12.13 \pm 1.27 \mathrm{~kg}$ ) were used to study the effect of utilization of sago waste as basal feed for their growth. The experiment was arranged in completely randomized design consisted of four diet treatments and six replications for each treatment. Goats were randomly allocated into diet treatments, they were: R0: $60 \%$ concentrate- $1+40 \%$ grass; R1: $60 \%$ concentrate- $2+40 \%$ sago waste silage (additive 10\% molasses); R2: 60\% concentrate- $2+40 \%$ sago waste silage (additive 10\% maize bran); and R3: $60 \%$ concentrate- $2+40 \%$ sago waste silage (additive $10 \%$ cassava meal). All treatment diets contained $12 \%$ crude protein and $2.8 \mathrm{kcal} / \mathrm{kg}$ digestible energy. The ration of feed was offered during thirteen weeks at $3.8 \%$ of body weight based on dry matter. The result of this experiment showed that dry matter intake, DM, OM, NDF, and ADF digestibility were not affected by diet treatments $(\mathrm{P}>0.05)$. Average daily gain on R1 and R3 treatments were significantly higher $(\mathrm{P}<0.05)$ from $\mathrm{R} 0$ treatment. It was concluded that sago waste silages with molasses and cassava meal as additives increased goat growth. Sago waste silages with molasses, maize bran, and cassava meal as additives were potential to be used as goat's feedstuff to replace of fibre sources.
\end{abstract}

Key Words: Sago, Silage, Basal Feed, Boerka Goat

\begin{abstract}
ABSTRAK
Ampas sagu merupakan limbah yang berasal dari pengolahan tanaman sagu menjadi tepung sagu memiliki potensi untuk digunakan sebagai pakan kambing. Penelitian ini bertujuan untuk mempelajari pengaruh penggunaan silase ampas sagu sebagai pakan basal terhadap pertumbuhan kambing Boerka. Sebanyak 24 ekor kambing Boerka jantan fase pertumbuhan (rata-rata bobot badan awal $12,13 \pm 1,27 \mathrm{~kg}$ ) digunakan untuk mempelajari pengaruh pemanfaatan silase ampas sagu sebagai pakan dasar terhadap pertumbuhannya. Rancangan yang digunakan adalah rancangan acak lengkap yang terdiri atas 4 perlakuan pakan dan 6 ulangan. Ternak secara acak dialokasikan ke dalam perlakuan pakan yaitu: R0: $60 \%$ konsentrat-1 60\% + 40\% rumput; R1: $60 \%$ konsentrat- $2+$ 40\% silase ampas sagu (bahan aditif molases 10\%); R2: $60 \%$ konsentrat-2 $+40 \%$ silase ampas sagu (bahan aditif dedak jagung 10\%); dan R3: 60\% konsentrat-2 + 40\% silase ampas sagu (bahan aditif tepung tapioka 10\%). Semua perlakuan pakan memiliki kandungan protein kasar $12 \%$ dan DE $2,8 \mathrm{Kkal} / \mathrm{kg}$. Pemberian pakan dilakukan selama 13 minggu sebanyak 3,8\% dari bobot badan berdasarkan bahan kering. Hasil penelitian menunjukkan konsumsi bahan kering pakan, kecernaan bahan kering, bahan organik, NDF dan ADF tidak dipengaruhi oleh perlakuan pakan $(\mathrm{P}>0,05)$. Pertambahan bobot hidup pada perlakuan pakan R1 dan R3 lebih besar dan berbeda nyata $(\mathrm{P}<0,05)$ dibandingkan dengan R0. Berdasarkan hasil penelitian disimpulkan bahwa silase ampas sagu dengan bahan aditif molases dan tepung tapioka meningkatkan pertumbuhan kambing. Silase ampas sagu bahan aditif molases, dedak jagung dan tepung tapioka potensial digunakan sebagai pakan dasar ternak kambing, juga merupakan bahan pakan alternatif untuk menggantikan komponen sumber serat.
\end{abstract}

Kata Kunci: Sagu, Silase, Pakan Basal, Kambing Boerka 


\section{PENDAHULUAN}

Hamparan tanaman sagu liar di Indonesia memiliki luas 1,4 juta hektar, sebagian besar terdapat di Papua dan Maluku (Syakir \& Karmawati 2013). Berdasarkan luasan tersebut dapat diproduksi sagu sebanyak 15 juta ton karena setiap batang sagu menghasilkan 200 $\mathrm{kg}$ sagu (Prastowo 2007). Ampas sagu (ela sagu) yang didapatkan pada proses pengolahan tepung sagu, menurut Rumalatu (1981) dalam proses pengolahan tepung sagu diperoleh tepung dan ampas sagu dengan perbandingan 1:6. Berdasarkan proporsi tersebut jumlah ampas sagu sebanyak 245.000 ton/hari. Jumlah hasil samping yang banyak sampai saat ini belum dimanfaatkan secara optimal, hanya dibiarkan menumpuk di lokasi pengolahan tepung sagu sehingga dapat menyebabkan pencemaran lingkungan. Hasil samping sagu ini cukup potensial untuk digunakan sebagai bahan pakan ternak ruminansia termasuk kambing. Kandungan nutrien yang terdapat pada limbah sagu seperti; protein kasar sebesar 3,36\%, NDF 67,40\%, ADF 42,11\% dan energi kasar 3.838 Kkal/kg (Nurkurnia 1989; Bintoro et al. 1990; Trisnowati 1991), relatif sebanding dengan nutrien rumput kecuali protein kasarnya. Kandungan protein kasar rumput berkisar 8,13-11,25\% (Ginting \& Tarigan 2006). Dengan kandungan zat nutrisi tersebut, maka limbah sagu diperkirakan hanya mampu memenuhi kebutuhan hidup pokok, sehingga untuk pertumbuhan, bunting dan laktasi diperlukan pakan tambahan untuk memenuhi kebutuhan protein dan energi. Simanihuruk et al. (2014) melaporkan bahwa ampas sagu kering dapat digunakan sebesar $40 \%$ dalam komponen pakan komplit kambing Boerka.

Limbah pengolahan sagu termasuk kategori limbah basah (wet by-products) karena masih mengandung kadar air 70-80\%, sehingga dapat rusak dengan cepat apabila tidak segera diproses. Perlakuan melalui pengeringan membutuhkan biaya yang relatif tinggi, sehingga perlu dikembangkan teknologi alternatif agar produk tersebut dapat dimanfaatkan lebih efisien. Teknologi silase adalah suatu proses fermentasi mikroba merubah pakan menjadi meningkat kandungan nutrisinya (protein dan energi) dan disukai ternak karena rasanya relatif manis. Silase merupakan proses mempertahankan kesegaran bahan pakan dengan kandungan bahan kering 30-35\% dan proses ensilase ini biasanya dalam silo atau dalam lobang tanah, atau wadah lain yang prinsipnya harus pada kondisi anaerob (hampa udara), agar mikroba anaerob dapat melakukan reaksi fermenfasi (Sapienza \& Bolsen 1993). Keberhasilan pembuatan silase berarti memaksimalkan kandungan nutrien yang dapat diawetkan. Selain bahan kering, kandungan gula juga merupakan faktor penting bagi perkembangan bakteri pembentuk asam laktat selama proses fermentasi (Khan et al. 2004). Pada fase awal proses ensilase, enzim yang bekerja dalam proses respirasi pada bahan, mengoksidasi karbohidrat yang terlarut, menghasilkan panas dan menggunakan gula-gula yang seyogianya siap pakai untuk proses fermentasi. Kehilangan gula pada proses respirasi merupakan hal yang menyulitkan baik dari sudut pandang pengawetan melalui proses pembuatan silase maupun dari segi nilai nutrisinya. Gula merupakan substrat bagi bakteri penghasil asam laktat yang akan menghasilkan asam yang berfungsi sebagai pengawet bahan yang disilase tersebut.

Mengingat ampas sagu mempunyai potensi yang tinggi sebagai bahan pakan ternak ruminansia termasuk kambing, maka perlu dilakukan penelitian pemanfaatan silase ampas sagu sebagai pakan dasar pengganti rumput pada ternak kambing. Penelitian ini bertujuan untuk mempelajari pengaruh penggunaan silase ampas sagu sebagai pakan dasar terhadap pertumbuhan kambing Boerka. 


\section{MATERI DAN METODE}

\section{Tempat dan waktu penelitian}

Penelitian ini dilaksanakan di kandang percobaan, Laboratorium Loka Penelitian Kambing Potong Sei Putih dan Laboratorium Fisiologi Nutrisi Ruminansia Balai Penelitian Ternak Ciawi, Bogor. Waktu pelaksanaan selama 5,5 bulan (persiapan bahan 1 bulan, adaptasi pakan 1 bulan dan pengumpulan data 3,5 bulan).

\section{Metode penelitian}

Ampas sagu diperoleh dari pabrik pengolahan tepung sagu di Kecamatan Sei Rampah Kabupaten Serdang Bedagai. Tahap awal pembuatan silase adalah melakukan pengurangan kadar air limbah sagu tersebut. Pengurangan kadar air dilakukan dengan menggunakan panas matahari selama $\pm 8-12$ jam tergantung intensitas sinar matahari sehingga kadar air limbah sagu tersebut berkisar 50-55\%, kemudian diproses silase melalui cara dicampur secara merata dengan masing-masing bahan aditif yaitu: molases/gula tetes $10 \%$, dedak jagung $10 \%$ atau tepung tapioka $10 \%$ untuk merangsang aktivitas mikroba dalam proses fermentasi dan untuk meningkatkan kandungan energi dan protein silase yang dihasilkan nantinya. Setelah dicampur merata dimasukkan ke dalam drum plastik (kapasitas $100 \mathrm{~kg}$ ), dipadatkan untuk meminimumkan udara (proses fermentasi anaerob). Kemudian disimpan ditempat teduh (bebas sinar matahari) selama \pm 3 minggu. Setelah tiga minggu diambil sampel ketiga jenis silase ampas sagu sebanyak $500 \mathrm{~g}$ untuk dianalisis kandungan nutriennya. Perlakuan pakan pada percobaan adalah sebagai berikut: R0: 60\% konsentrat- $1+40 \%$ rumput; R1: $60 \%$ konsentrat $-2+40 \%$ silase ampas sagu (bahan aditif molases 10\%); R2: $60 \%$ konsentrat- $2+40 \%$ silase ampas sagu (bahan aditif dedak jagung 10\%); R3: $60 \%$ konsentrat $-2+40 \%$ silase ampas sagu (bahan aditif tepung tapioka 10\%).

\section{Uji biologis silase ampas sagu}

Digunakan 24 ekor kambing jantan Boerka fase pertumbuhan (umur 8-9 bulan) dengan rerata bobot badan $12,13 \pm 1,27 \mathrm{~kg}$, ditempatkan dalam kandang individu, dilengkapi dengan palaka yang terbuat dari papan. Air minum disediakan secara bebas dalam ember plastik hitam berkapasitas lima liter. Ternak secara acak dialokasikan ke dalam 4 perlakuan pakan (enam ekor per perlakuan).

Rumput lapangan (Ottochloa nodusa) sebagai sumber hijauan diperoleh dari areal perkebunan PTPN III Sei Putih. Bahan penyusun konsentrat adalah: dedak halus, jagung giling, bungkil kelapa, urea, tepung ikan, tepung tulang, ultra mineral dan garam. Konsentrat-1 untuk perlakuan pakan R0 berbeda kandungan energi dan proteinnya dengan konsentrat-2 untuk R1; R2 dan R3 sehingga setelah diketahui kandungan nutrisi silase limbah sagu maka setiap perlakuan pakan diupayakan memiliki kandungan energi sebesar DE 2,8 Mkal/kg dan $12 \%$ protein kasar. Pemberian pakan disesuaikan dengan kebutuhan bahan kering pakan untuk setiap ekor kambing dan ditentukan sebesar 3,8\% dari bobot badan berdasarkan bahan kering (NRC 1981). Komponen konsentrat, hijauan dan silase limbah sagu pada penelitian ini berbeda waktu pemberiannya. Konsentrat diberikan pada pagi hari jam 9.00 WIB, hijauan diberikan siang hari jam 11.30 WIB dan silase limbah sagu diberikan kepada ternak percobaan pada sore hari jam 14.30 WIB. Hal ini dilakukan untuk mengoptimalkan konsumsi terhadap komponen pakan yang diberikan. Ternak dibiarkan beradaptasi dengan perlakuan pakan selama 4 minggu sebelum pengumpulan data dilakukan. Konsumsi pakan dicatat setiap hari dengan menimbang jumlah yang 
diberikan dan sisanya. Pertambahan bobot badan harian diperoleh dari penimbangan ternak penelitian setiap minggu selama 13 kali penimbangan.

Untuk mengetahui tingkat kemampuan ternak mencerna nutrien yang dikonsumsi dilakukan pada minggu terakhir masa pengamatan, dengan cara menimbang jumlah pemberian dan sisa pakan serta jumlah produksi feses dan urin yang dihasilkan setiap hari selama enam hari pengamatan. Contoh bahan (pakan, sisa pakan dan feses) ditimbang dan selanjutnya untuk kepentingan analisis, ditetapkan subcontoh sebanyak $10 \%$ dari jumlah koleksi setiap harinya. Subcontoh selama periode pengamatan disatukan dalam satu kantong plastik dan secara komposit ditetapkan $10 \%$ untuk kepentingan analisis. Contoh yang telah kering dihaluskan dengan alat penghalus dan melewati saringan yang berukuran $0,8 \mathrm{~mm}$.

Analisis kimia sampel pakan (konsentrat, rumput alam dan ketiga jenis silase ampas sagu) dilakukan sesuai dengan metode analisis proksimat. Analisis bahan kering dilakukan dengan metode pemanasan di dalam oven $60^{\circ} \mathrm{C}$ selama 48 jam dan $140^{\circ} \mathrm{C}$ selama 2 jam. Analisis protein kasar dilakukan dengan cara mengukur kandungan total nitrogen contoh dengan menggunakan macro-Kjeldahl (AOAC 1995). Analisis kandungan serat (serat detergen netral dan serat detergen asam) ditentukan menurut metode Goering \& Van Soest (1970), kandungan energi ditentukan dengan menggunakan alat bomb kalorimeter, sedangkan kandungan abu dilakukan dengan membakar contoh dalam tanur dengan suhu pembakaran $600^{\circ} \mathrm{C}$ selama 6 jam.

\section{Peubah yang diamati}

Peubah yang diamati adalah tingkat konsumsi pakan, pertambahan bobot hidup harian (PBHH), efisiensi penggunaan pakan, income over feed cost (IOFC) dan kecernaan pakan. Pengamatan jumlah konsumsi dilakukan setiap hari dengan cara menimbang jumlah pakan yang diberikan dan sisa pada keesokan harinya. Pertambahan bobot hidup harian dihitung berdasarkan data bobot hidup yang diperoleh dari penimbangan ternak setiap minggu selama 13 minggu masa pengamatan. Efisiensi penggunaan pakan dihitung berdasarkan data pertambahan bobot hidup per unit bahan kering pakan yang dikonsumsi. Income over feed cost dihitung berdasarkan penerimaan yang diperoleh dari penjualan ternak setelah dikurangi biaya pakan. Kecernaan pakan diukur selama 6 hari dengan persamaan:

$$
\text { Kecernaan }=\frac{\text { Zat makanan yang dikonsumsi- zat makanan di feses }}{\text { Zat makanan yang dikonsumsi }} \times 100 \%
$$

\section{Rancangan penelitian}

Percobaan ini menggunakan rancangan acak lengkap (RAL) yang terdiri dari atas 4 perlakuan pakan dan 6 ulangan (Steel \& Torrie 1993). Setiap ulangan terdiri atas satu ekor kambing, sehingga jumlah ternak yang digunakan dalam penelitian ini sebanyak 24 ekor. Data yang diperoleh diolah dengan analisis keragaman (ANOVA) dan bila hasil analisis keragaman menunjukkan terdapat pengaruh nyata $(\mathrm{P}<0,05)$ dari perlakuan terhadap peubah yang diukur, maka dilanjutkan dengan uji jarak berganda Duncan (Kaps \& Lamberson 2004). Model umum dari rancangan ini adalah:

$$
\begin{array}{rlll}
\multicolumn{3}{c}{\mathrm{Y}_{\mathrm{ij}}=\mu+\alpha_{\mathrm{ij}}+} & \varepsilon_{\mathrm{ij}} \\
\mathrm{Y}_{\mathrm{ij}} & =\text { Respon peubah yang diamati } & \varepsilon_{\mathrm{ij}} & =\text { Pengaruh komponen galat } \\
\mu & \text { = Rata-rata umum } & \mathrm{i} & =1,2,3,4 \\
\alpha_{\mathrm{ij}} & =\text { Pengaruh pakan ke-i pada ulangan ke-j } \quad \mathrm{j} & =1,2,3,4,5,6
\end{array}
$$




\section{HASIL DAN PEMBAHASAN}

\section{Komposisi kimia pakan penelitian}

Komposisi kimia pakan yang digunakan pada penelitian ini disajikan pada Tabel 1. Kandungan energi kasar ketiga jenis silase yaitu sebesar 3.803-3.845 kkal/kg. Kandungan protein kasar ketiga jenis silase yaitu sebesar 3,84-4,48\%. Berdasarkan kandungan protein kasar dan energi kasar ketiga jenis silase ampas sagu menunjukkan bahwa perlakuan silase dapat meningkatkan kandungan protein kasar (relatif kecil) dan energi kasar (relatif besar) dibandingkan dengan yang didapatkan oleh Simanihuruk et al. (2014) yang menyatakan bahwa protein kasar ampas sagu sebesar 3,07\% dan energi kasarnya sebesar $3.757 \mathrm{kkal} / \mathrm{kg}$. Kandungan NDF ketiga jenis silase yaitu sebesar 43,55-47,78\%. Kandungan ADF ketiga jenis silase yaitu sebesar 31,37-37,84\%.

Tabel 1. Komposisi kimiawi pakan penelitian

\begin{tabular}{lcccccc}
\hline \hline Jenis bahan pakan & GE $(\mathrm{kkal} / \mathrm{kg})$ & $\mathrm{BK}(\%)$ & $\mathrm{Abu}(\%)$ & $\mathrm{PK}(\%)$ & $\mathrm{NDF}(\%)$ & ADF $(\%)$ \\
\hline Silase ampas sagu A & 3.845 & 33,20 & 6,56 & 3,84 & 43,55 & 31,37 \\
Silase ampas sagu B & 3.808 & 36,35 & 5,77 & 4,08 & 47,78 & 37,84 \\
Silase ampas sagu C & 3.803 & 36,78 & 5,25 & 4,48 & 45,81 & 35,21 \\
Rumput lapangan & 3.701 & 16,34 & 7,95 & 7,37 & 58,03 & 47,55 \\
Konsentrat 1 & 3.852 & 89,57 & 10,83 & 15,78 & 24,43 & 10,12 \\
Konsentrat 2 & 3.756 & 89,83 & 10,97 & 17,91 & 24,62 & 10,98 \\
\hline
\end{tabular}

Kandungan potein kasar rumput lapang yang digunakan pada penelitian ini adalah sebesar 7,37\%, angka ini relatif sebanding dengan yang didapatkan Sirait et al. (2005) yang menyatakan bahwa kandungan protein kasar rumput di Indonesia sekitar 7-14\%. Kandungan protein kasar konsentrat 1 lebih kecil dari konsentrat 2 (15,78 vs 17,91\%). Hal ini dilakukan agar protein kasar keempat perlakuan pakan relatif sebanding, karena kandungan protein kasar rumput lapang lebih tinggi dibandingkan dengan ketiga jenis silase ampas sagu.

\section{Konsumsi bahan kering pakan}

Rerata konsumsi bahan kering konsentrat keempat perlakuan adalah berkisar antara 317,70-338,81 g/ekor/hari. Rerata konsumsi bahan kering ketiga jenis silase ampas sagu adalah berkisar antara 238,53-251,95 g/ekor/hari. Rerata konsumsi bahan kering pakan selama penelitian untuk keempat perlakuan adalah berkisar antara 533,34-577,34 g/ekor/hari seperti disajikan dalam Tabel 2. Hasil analisis keragaman menunjukkan bahwa total konsumsi bahan kering pakan tidak dipengaruhi oleh perlakuan pakan $(\mathrm{P}>0,05)$. Konsumsi bahan kering pakan keempat perlakuan berdasarkan persentase bobot hidup adalah berkisar antara 3,21-3,41\%. Konsumsi bahan kering yang relatif sama pada keempat perlakuan pakan diduga karena silase ampas sagu memiliki palatabilitas yang cukup tinggi. Molases, dedak jagung dan tepung tapioka yang digunakan sebagai bahan aditif silase ampas sagu pada penelitian ini diduga mempengaruhi palatabilitas ampas sagu. Kandungan gula yang terdapat pada silase ampas sagu dapat menjadi salah satu faktor yang mempengaruhi palatabilitas (Charray et al. 1992). 
Tabel 2. Konsumsi bahan kering pakan

\begin{tabular}{lcccc}
\hline \hline \multirow{2}{*}{ Uraian } & \multicolumn{4}{c}{ Perlakuan pakan } \\
\cline { 2 - 5 } & $\mathrm{R} 0$ & $\mathrm{R} 1$ & $\mathrm{R} 2$ & $\mathrm{R} 3$ \\
\hline $\begin{array}{l}\text { Konsumsi konsentrat } \\
\text { (g/ekor/hari) }\end{array}$ & $317,70 \pm 13,53^{\mathrm{a}}$ & $338,81 \pm 18,87^{\mathrm{a}}$ & $318,98 \pm 34,68^{\mathrm{a}}$ & $320,35 \pm 32,12^{\mathrm{a}}$ \\
$\begin{array}{l}\text { Konsumsi rumput } \\
\text { (g/ekor/hari) }\end{array}$ & $215,64 \pm 15,74$ & 0 & 0 & 0 \\
$\begin{array}{l}\text { Konsumsi silase ampas } \\
\text { sagu (g/ekor/hari) }\end{array}$ & 0 & $238,54 \pm 12,79^{\mathrm{a}}$ & $251,95 \pm 20,33^{\mathrm{a}}$ & $247,13 \pm 22,15^{\mathrm{a}}$ \\
$\begin{array}{l}\text { Total konsumsi pakan } \\
\text { (g/ekor/hari) }\end{array}$ & $533,34 \pm 20,48^{\mathrm{a}}$ & $577,35 \pm 23,34^{\mathrm{a}}$ & $570,93 \pm 30,97^{\mathrm{a}}$ & $567,48 \pm 31,81^{\mathrm{a}}$ \\
$\%$ Bobot hidup & 3,21 & 3,41 & 3,40 & 3,39 \\
\hline
\end{tabular}

Huruf yang sama pada baris yang sama menunjukkan tidak ada perbedaan nyata $(\mathrm{P}>0,05)$; $\mathrm{R} 0$ : $60 \%$ konsentrat- $1+40 \%$ rumput; R1: $60 \%$ konsentrat $2+40 \%$ silase ampas sagu (bahan aditif molases 10\%); R2: $60 \%$ konsentrat- $2+40 \%$ silase ampas sagu (bahan aditif dedak jagung 10\%); R3: $60 \%$ konsentrat- $2+40 \%$ silase ampas sagu (bahan aditif tepung tapioka 10\%)

Konsumsi bahan kering pakan tidak berbeda nyata antar perlakuan pakan. Padahal diketahui bahwa bahan aditif molases memiliki kandungan gula-gula sederhana dan rasanya manis sehingga dapat mempengaruhi palatabilitas sekaligus meningkatkan konsumsi pakan. Morand-Fehr (2003); Ginting et al. (2007) dan Simanihuruk et al. (2012) menyatakan bahwa kandungan gula yang terdapat pada suatu jenis bahan pakan dapat meningkatkan konsumsi pada ternak kambing. Pada taraf penelitian ini belum terlihat.

\section{Kecernaan pakan}

Rerata kecernaan bahan kering keempat perlakuan adalah berkisar 60,38-65,47\% seperti yang disajikan pada Tabel 3. Hasil analisis keragaman menunjukkan bahwa kecernaan bahan kering tidak dipengaruhi oleh perlakuan pakan $(\mathrm{P}>0,05)$. Kecernaan bahan kering keempat perlakuan pakan relatif sebanding. Hal ini terjadi diduga terkait dengan konsumsi bahan kering pakan yang juga tidak dipengaruhi oleh perlakuan pakan. Ginting et al. (2007) melaporkan bahwa kambing Boerka jantan sedang tumbuh yang diberi pakan silase limbah nenas 50\% + konsentrat 50\% kecernaan bahan kering pakannya adalah sebesar $64,40 \%$, angka relatif sebanding dengan perlakuan pakan R3 pada penelitian ini.

Rerata kecernaan bahan organik keempat perlakuan adalah berkisar antara 61,47$67,03 \%$. Hasil analisis keragaman menunjukkan bahwa kecernaan bahan organik juga tidak dipengaruhi oleh perlakuan pakan $(\mathrm{P}>0,05)$. Keadaan ini berlaku terkait dengan kecernaan bahan kering yang juga tidak dipengaruhi oleh perlakuan pakan, karena sebahagian besar bahan kering terdiri atas bahan organik (McDonald et al. 2002). Bahan kering terdiri atas bahan organik dan abu (mineral), kecernaan bahan organik pada penelitian ini lebih tinggi dibandingkan dengan kecernaan bahan kering. Hal ini terjadi kemungkinan karena kecernaan mineral pada penelitian ini relatif rendah.

Rerata kecernaan NDF keempat perlakuan adalah berkisar antara 60,06-62,83\%. Hasil analisis keragaman menunjukkan bahwa kecernaan NDF tidak dipengaruhi oleh perlakuan pakan $(\mathrm{P}>0,05)$. Keadaan ini terjadi terkait dengan konsumsi dan kecernaan bahan kering yang juga tidak dipengaruhi oleh perlakuan pakan. Selain itu juga karena kandungan protein pada keempat pakan perlakuan relatif sama. Pertumbuhan bakteri pencerna serat di 
dalam rumen dipengaruhi oleh kandungan nitrogen pakan (Grant \& Mertens 1992). Ratarata kecernaan ADF keempat perlakuan adalah berkisar antara 57,71-59,34\%. Hasil analisis keragaman menunjukkan bahwa kecernaan ADF juga tidak dipengaruhi oleh perlakuan pakan $(\mathrm{P}>0,05)$. Keadaan ini terjadi terkait dengan kecernaan NDF yang juga tidak dipengaruhi oleh perlakuan pakan, karena NDF terdiri atas ADF dan hemiselulosa (Cheeke 1999).

Tabel 3. Kecernaan bahan kering, bahan organik, NDF dan ADF

\begin{tabular}{lcccc}
\hline \multirow{2}{*}{ Uraian } & \multicolumn{4}{c}{ Perlakuan pakan } \\
\cline { 2 - 5 } & R0 & R1 & R2 & R3 \\
\hline Kecernaan: & & & \\
Bahan kering (\%) & $60,38 \pm 2,37^{\mathrm{a}}$ & $65,47 \pm 4,28^{\mathrm{a}}$ & $63,56 \pm 5,52^{\mathrm{a}}$ & $63,89 \pm 4,17^{\mathrm{a}}$ \\
Bahan organik (\%) & $61,47 \pm 1,98^{\mathrm{a}}$ & $67,03 \pm 3,21^{\mathrm{a}}$ & $64,77 \pm 5,06^{\mathrm{a}}$ & $65,12 \pm 3,95^{\mathrm{a}}$ \\
NDF (\%) & $60,06 \pm 1,43^{\mathrm{a}}$ & $62,83 \pm 2,53^{\mathrm{a}}$ & $62,03 \pm 3,28^{\mathrm{a}}$ & $62,11 \pm 3,18^{\mathrm{a}}$ \\
ADF (\%) & $57,49 \pm 1,21^{\mathrm{a}}$ & $59,34 \pm 2,07^{\mathrm{a}}$ & $58,98 \pm 2,70^{\mathrm{a}}$ & $59,07 \pm 2,93^{\mathrm{a}}$ \\
\hline
\end{tabular}

Huruf yang sama pada baris yang sama menunjukkan tidak ada perbedaan nyata $(\mathrm{P}>0,05)$; $\mathrm{R} 0$ : $60 \%$ konsentrat- $1+40 \%$ rumput; R1: $60 \%$ konsentrat $2+40 \%$ silase ampas sagu (bahan aditif molases 10\%); R2: $60 \%$ konsentrat- $2+40 \%$ silase ampas sagu (bahan aditif dedak jagung 10\%); R3: $60 \%$ konsentrat- $2+40 \%$ silase ampas sagu (bahan aditif tepung tapioka 10\%)

\section{Pertambahan bobot hidup dan efisiensi penggunaan pakan}

Pertumbuhan merupakan peningkatan dalam struktur jaringan otot, tulang dan organ serta deposit lemak pada jaringan adipose. Dari data pertambahan bobot hidup akan diketahui nilai suatu bahan pakan bagi ternak (Church \& Pond 1995).

Tabel 4. Rata-rata pertambahan bobot hidup dan efisiensi penggunaan pakan

\begin{tabular}{lcccc}
\hline \multirow{2}{*}{ Uraian } & \multicolumn{4}{c}{ Perlakuan pakan } \\
\cline { 2 - 5 } & $\mathrm{R} 0$ & $\mathrm{R} 1$ & $\mathrm{R} 2$ & $\mathrm{R} 3$ \\
\hline Bobot hidup awal $(\mathrm{kg})$ & $12,17 \pm 1,31$ & $12,12 \pm 1,28$ & $12,10 \pm 1,26$ & $12,13 \pm 1,23$ \\
Bobot hidup akhir $(\mathrm{kg})$ & $18,83 \pm 2,97$ & $20,77 \pm 3,12$ & $19,93 \pm 2,76$ & $20,50 \pm 2,84$ \\
Pertambahan bobot hidup & $73,26 \pm 7,83^{\mathrm{b}}$ & $95,05 \pm 9,78^{\mathrm{a}}$ & $86,08 \pm 8,38^{\text {ab }}$ & $91,94 \pm 9,98^{\mathrm{a}}$ \\
(g/ekor/hari) & & & & \\
Pertambahan bobot (kg) & $6,67 \pm 0,73$ & $8,65 \pm 0,98$ & $7,83 \pm 0,87$ & $8,37 \pm 0,83$ \\
Efisiensi penggunaan pakan & $0,138 \pm 0,015$ & $0,165 \pm 0,021$ & $0,151 \pm 0,017$ & $0,162 \pm 0,016$ \\
\hline
\end{tabular}

Huruf yang berbeda pada baris yang sama menunjukkan perbedaan nyata $(\mathrm{P}<0,05)$; R0: $60 \%$ konsentrat- $1+40 \%$ rumput; R1: $60 \%$ konsentrat $-2+40 \%$ silase ampas sagu (bahan aditif molases 10\%); R2: 60\% konsentrat-2 + 40\% silase ampas sagu (bahan aditif dedak jagung 10\%); R3: 60\% konsentrat- $2+40 \%$ silase ampas sagu (bahan aditif tepung tapioka 10\%)

Rata-rata pertambahan bobot hidup harian keempat perlakuan adalah berkisar antara 73,26-95,05 g/ekor/hari seperti disajikan pada Tabel 4. Hasil analisis keragaman menunjukkan bahwa pertambahan bobot hidup harian dipengaruhi oleh perlakuan pakan $(\mathrm{P}<0,05)$. Pertambahan bobot hidup harian perlakuan pakan R1 dan R3 secara statistik nyata lebih besar dibandingkan dengan R0, sedangkan pertambahan bobot hidup harian perlakuan pakan R2 tidak berbeda nyata dibandingkan dengan R0, R1 dan R3. Keadaan ini 
berlaku diduga terkait dengan kandungan gula sederhana yang terdapat pada silase ampas sagu yang menggunakan bahan aditif molases dan tepung tapioka (perlakuan pakan R1 dan R3) lebih tinggi dibandingkan dengan R0 dan R2. Kandungan gula sederhana yang terdapat pada campuran pakan akan lebih efisien diproses tubuh ternak untuk pertumbuhannya (Morand-Fehr 2003).

Ginting et al. (2007) melaporkan bahwa kambing Boerka jantan sedang tumbuh yang diberi silase limbah nanas $25 \%+$ konsentrat $75 \%$ dalam komponen pakan pertambahan bobot hidupnya adalah sebesar 87,10 g/ekor/hari. Angka ini relatif sebanding dengan pertambahan bobot hidup perlakuan pakan R2 pada penelitian ini.

Efisiensi penggunaan pakan keempat perlakuan adalah berkisar antara 0,138-0,165. Efisiensi penggunaan pakan terbesar diperoleh pada perlakuan pakan R1 dan R3. Hal ini berlaku terkait dengan konsumsi bahan kering pakan dan pertambahan bobot hidup, karena efisiensi penggunaan pakan adalah rasio antara pertambahan bobot badan dengan jumlah pakan yang dikonsumsi (Tillman et al. 1998). Efisiensi penggunaan pakan pada perlakuan pakan R0 tergolong kategori moderat, karena $1 \mathrm{~kg}$ bahan kering pakan dapat menghasilkan pertambahan bobot hidup sebesar $138 \mathrm{~g}$. Efisiensi penggunaan pakan pada perlakuan pakan R1, R2 dan R3 relatif tinggi karena $1 \mathrm{~kg}$ bahan kering pakan dapat menghasilkan pertambahan bobot hidup sebesar 165, 151 dan 162 g. Ginting et al. (2007) melaporkan bahwa efisiensi penggunaan pakan kambing Boerka yang diberi pakan 50\% silase limbah nanas dan 50\% konsentrat adalah sebesar 0,133 yang lebih rendah dibandingkan dengan hasil penelitian ini.

\section{Income over feed cost (IOFC)}

Nilai ekonomi pemanfaatan silase ampas sagu pada penelitian ini dapat diketahui dengan menghitung income over feed cost (pendapatan yang diperoleh dari nilai jual ternak setelah dikurangi biaya pakan). Pengaruh penggunaan silase ampas sagu sebagai pakan basal pengganti rumput terhadap rerata nilai IOFC dicantumkan pada Tabel 5. Harga per kilogram rumput dan ketiga jenis silase ditentukan setelah memperhitungkan biaya tenaga kerja dan bahan-bahan lain yang digunakan. Harga per kilogram silase ampas sagu A lebih murah dibandingkan dengan silase ampas sagu B dan C. Hal ini berlaku karena harga per kilogram molases lebih murah dibandingkan dengan dedak jagung dan tepung tapioka. Harga per kilogram konsentrat diketahui melalui harga dan jumlah masing-masing campuran bahan konsentrat yang digunakan pada penelitian ini. Harga jual per kilogram bobot hidup kambing penelitian ditentukan berdasarkan harga yang berlaku disekitar kabupaten Deli Serdang.

Rerata nilai IOFC keempat perlakuan adalah berkisar antara 215.085-333.497 rupiah per ekor. Meskipun harga rumput lebih rendah dibandingkan dengan harga silase ampas sagu yang menggunakan bahan aditif molases (600 vs 1.000), tetapi nilai IOFC perlakuan pakan R1 lebih besar dibandingkan R0. Hal ini berlaku selain karena pertambahan bobot hidup pada perlakuan pakan R1 lebih besar dibandingkan dengan R0, juga karena bahan kering silase ampas sagu (bahan aditif molases) lebih besar dibandingkan rumput. Konsumsi ketiga jenis silase pada perlakuan pakan R1, R2 dan R3 relatif sebanding, walaupun demikian nilai IOFC perlakuan pakan R1 lebih besar dibandingkan dengan R2 dan R3 (Tabel 5). Keadaan ini terjadi selain karena pertambahan bobot hidup pada perlakuan pakan R1 lebih besar dibandingkan R0, juga karena harga bahan aditif molases cukup rendah. 
Tabel 5. Analisis ekonomi pemanfaatan silase ampas sagu pada kambing Boerka

\begin{tabular}{|c|c|c|c|c|}
\hline \multirow{2}{*}{ Uraian } & \multicolumn{4}{|c|}{ Perlakuan pakan } \\
\hline & (R0) & (R1) & $(\mathrm{R} 2)$ & (R3) \\
\hline \multicolumn{5}{|l|}{ Konsumsi pakan (segar) } \\
\hline Konsentrat (kg/ekor) & 32,30 & 34,32 & 32,31 & 32,45 \\
\hline Rumput (kg/ekor) & 120,09 & 0,00 & 0,00 & 0,00 \\
\hline Silase ampas sagu (kg/ekor) & 0 & 65,38 & 63,07 & 61,14 \\
\hline \multicolumn{5}{|l|}{ Harga dan biaya pakan (Rp) } \\
\hline Konsentrat (Rp. 3500/kg) & 113.059 & 120.120 & 113.085 & 113.575 \\
\hline Rumput (Rp. 600/kg) & 72.056 & 0,00 & 0,00 & 0,00 \\
\hline Silase ampas sagu A (Rp. 1.000/kg) & 0,00 & 65.383 & & \\
\hline Silase ampas sagu B (Rp. 1.100/kg) & & & 69.382 & \\
\hline Silase ampas sagu C (Rp. 1.200/kg) & & & & 73.373 \\
\hline Jumlah biaya pakan (Rp./ekor) & 185.115 & 185.503 & 182.467 & 186.738 \\
\hline Rerata PBH (kg/ekor) & 6,67 & 8,65 & 7,83 & 8,37 \\
\hline Nilai jual (Rp./ekor)* & 400.200 & 519.000 & 469.800 & 502.200 \\
\hline IOFC (Rp./ekor selama 13 minggu) & 215.085 & 333.497 & 287.333 & 315.252 \\
\hline
\end{tabular}

*Harga jual ternak Rp 60.000/kg bobot hidup; PBH: Pertambahan bobot hidup

\section{KESIMPULAN}

Penggunaan silase ampas sagu bahan aditif molasses dan tepung tapioka meningkatkan pertumbuhan 22,92 dan 19,65\% dibandingkan kontrol. Silase ampas sagu bahan aditif molasses, dedak jagung dan tepung tapioka potensial digunakan sebagai bahan pakan basal ternak kambing, juga merupakan bahan pakan alternatif untuk menggantikan komponen sumber serat. Perlu dilakukan penelitian lebih lanjut (menggunakan teknologi fermentasi yang berbeda) untuk meningkatkan kandungan protein kasar ampas sagu.

\section{DAFTAR PUSTAKA}

AOAC. 1995. Official methods of analysis. $16^{\text {th }}$ Ed. In: K Helrich, editor. Association of Official Analytical Chemist, Inc. Arlington (USA): Association of Analytical Communities.

Bintoro MHB, Hariyanto, Honigone T, Marangkey MP, Sakaguchi E, Takamura Y. 1990. Feeding value of pith and pith residue from sago palm. In: Proceeding Takahashi-Shi Nutrition Conference, Okayama. p. 1-12.

Charray J, Humbert JM, Levif J. 1992. Manual of sheep production in the humid tropic of Africa. Wallingford (UK): CAB International.

Cheeke PR. 1999. Applied animal nutrition feeds and feeding. $2^{\text {nd }}$ Ed. New Jersey (USA): Prentice Hall, Upper Saddle River.

Church DC, Pond WG. 1995. Basic animal nutrition and feeding. $2^{\text {nd }}$ Ed. New Yersey (USA): Prentice Hall, Upper Saddle River.

Ginting SP, Tarigan A. 2006. Kualitas nutrisi Stenotaphrum secundatum dan Brachiaria humidicola pada kambing. JITV. 11:273-279. 
Ginting SP, Krisnan R, Simanihuruk K. 2007. Silase kulit nanas sebagai pakan dasar pada kambing persilangan Boer $\times$ Kacang sedang tumbuh. JITV. 12:195-201.

Goering HK, Van Soest PJ. 1970. Forage fiber analyses (apparatus, reagents, procedures and some application). Agricultural Handbook 379. Washington DC (USA): ARS USDA.

Grant RJ, Mertens DR. 1992. Impact of in vitro fermentation techniques upon kinetics of fiber digestion. J Dairy Sci. 75:1263-1272.

Kaps M, Lamberson WR. 2004. Biostatistic for animal science. Cambridge (USA): CAB International Publishing.

Khan MA, Sarwar M, Khan MMS. 2004. Feeding value of urea treated corncobs ensiled with or without enzose (corn dextrose) for lactating crossbred cows. Asian-Australian J Anim Sci. 8:1093-1097.

McDonald P, Edwards RA, Greenhalg JFD, Morgan CA. 2002. Animal nutrition. $6^{\text {th }}$ Ed. Ashford Colour Pr. Gosfort.

Morand-Fehr P. 2003. Dietary choices of goats at the trough. Small Rum Res. 49:231-239.

NRC. 1981. Nutrient requirement of goats: Angora, Dairy, and meat goats in temperate and tropical countries. Washington DC (USA): National Research Council, National Academy Pr.

Nurkurnia E. 1989. Hasil fermentasi rumen kambing Kacang betina dengan pemberian beberapa tingkat ampas sagu (Metroxylon sp) dalam ransum [Skripsi]. [Bogor (Indonesia)]: Institut Pertanian Bogor.

Prastowo B. 2007. Potensi sektor pertanian sebagai penghasil dan pengguna energi terbarukan. Perspektif. 6:84-92.

Rumalatu FJ. 1981. Distribusi dan potensi pati beberapa sagu (Metroxylon sp) di daerah Seram Barat [Skripsi]. [Bogor (Indonesia)]: Institut Pertanian Bogor.

Sapienza DA, Bolsen KK. 1993. Teknologi silase (penanaman, pembuatan dan pemberiannya pada ternak). Dalam: Martoyondo RBS, penerjemah.

Simanihuruk K, Chaniago A, Sirait J. 2012. Silase ampas sagu sebagai pakan dasar kambing Kacang sedang tumbuh. Dalam: Prasetyo LH, Damayanti R, Iskandar S, Herawati T, Priyanto D, Puastuti W, Anggraeni A, Tarigan S, Wardhana AH, Darmayanti NLPI, et al., penyunting. Teknologi Peternakan dan Veteriner Untuk Peningkatan Produksi dan Antisipatif terhadap Dampak Perubahan Iklim. Prosiding Seminar Nasional Teknologi Peternakan dan Veteriner. Bogor, 7-8 Juni 2011. Bogor (Indonesia): Puslitbangnak. hlm. 542-550.

Simanihuruk K, Antonius, Sirait J. 2014. Usage of sago waste as component of complete feed for growing Boerka goats. In: Subandriyo, Kusmartono, Santoso KA, Kurnianto E, Purnomoadi A, Sodiq A, Wiryawan KG, Darodjah S, Inounu I, Darmono, Priyanti A, Wynn P, Han JL, Tay-Hsu J, Idrus Z, et al., editors. Sustainable Livestock Production in the Prespective of Food Security, Policy, Genetic Resources, and Climate Change. Proceedings of the $16^{\text {th }}$ AAAP Animal Science Congress. Yogyakarta, 10-14 November 2014. Yogyakarta (Indonesia): Gadjah Mada University. p. 1885-1889.

Sirait J, Purwantari ND, Simanihuruk K. 2005. Produksi dan serapan nitrogen rumput pada naungan dan pemupukan yang berbeda. JITV. 10:175-181.

Steel RGD, Torrie JH. 1993. Prinsip dan prosedur statistika: Suatu pendekatan biometrik. Sumantri B, penerjemah. Jakarta: Gramedia.

Syakir M, Karmawati E. 2013. Potensi tanaman sagu (Metroxylon spp) sebagai bahan baku bioenergi. Perspektif. 12:57-64.

Tillman DA, Hartadi H, Reksohadiprodjo S, Prawirokusumo S, Lebdosoekotjo S. 1998. Ilmu makanan ternak dasar. Cetakan ke-5. Yogyakarta (Indonesia): Universitas Gadjah Mada. 
Trisnowati 1991. Kecernaan in vitro ampas sagu metroxylon yang diperlakukan secara biologis [Skripsi]. [Bogor (Indonesia)]: Institut Pertanian Bogor.

\section{DISKUSI}

\section{Pertanyaan}

Apakah kambing Boerka itu? Dan mengapa menggunakannya?

\section{Jawaban}

Kambing Boerka adalah persilangan kambing Boer dan Kacang. Penelitian dilakukan untuk mendukung produktivitas ternak kambing Boerka. 